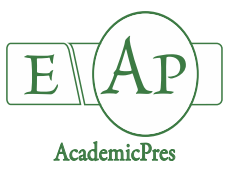

Deng Z et al. (2021)

Notulae Botanicae Horti Agrobotanici Cluj-Napoca

Volume 49, Issue 1, Article number 12190

DOI: $10.15835 /$ nbha49112190

Research Article

\title{
Screening high potassium efficiency potato genotypes and physiological responses at different potassium levels
}

\author{
Zhenpeng DENG ${ }^{1,2}$, Jin YANG ${ }^{1,2}$, Yuanya $\mathrm{CHEN}^{1,2}$, Haohao HAN $^{1,2}$, \\ Xun LIU ${ }^{1,2}$, Xiaoping YI ${ }^{1,2}$, Jichun WANG ${ }^{1,2}$, Changwen LYU ${ }^{1,2 *}$ \\ ${ }^{1}$ Southwest University, College of Agronomy and Biotechnology, Nr. 2 Rd Tiansheng, Beibei, Chongqing, China; \\ zhenpenger@gmail.com;965346814@qq.com; cyy5848@sina.com; haohaohao202020@163.com; liuxun828@swu.edu.cn; \\ xiaopingyi@swu.edu.cn; wjchun@swu.edu.cn; Ivcgwn@swu.edu.cn (*corresponding author) \\ ${ }^{2}$ Chongqing Key Laboratory of Biology and Genetic Breeding for Tuber and Root Crops, College of Agronomy and Biotechnology, \\ Southwest University, Nr. 2 Rd Tiansheng, Beibei, Chongqing, China
}

\begin{abstract}
Potato (Solanum tuberosum L.) growth and production is highly dependent on potassium (K) levels in the soil. Southwest China is the largest potato production region but it has low availability of soil potassium. To assess the genetic variation in K use efficiency, 20 potato genotypes were collected to compare the yield and K content in a pot experiment. Moreover, 'Huayu- 5 ' and 'Zhongshu-19' were cultivated in five K applications to investigate the $\mathrm{K}$ distribution and sucrose in different organs. The results indicated that there were highly significant effects of $\mathrm{K}$, genotype and $\mathrm{K} \times \mathrm{G}$ interactions on tuber yield, plant and tuber $\mathrm{K}$ content, plant $\mathrm{K}$ uptake efficiency and K harvest index. Cluster analysis classified 20 potato genotypes into four types: $\mathrm{DH}$ (high efficiency at low and high $\mathrm{K}$ application), $\mathrm{LKH}$ (high efficiency at low $\mathrm{K}$ application), $\mathrm{HKH}$ (high efficiency at high $\mathrm{K}$ application) and DL (low efficiency at low and high $\mathrm{K}$ application). The potassium distribution percentage in the tubers of the potassium-efficient genotype was higher than that of the potassium-inefficient genotype under low potassium application. The sucrose content in the tuber gently declined as the application of $\mathrm{K}$ rose in both cultivars, and that in the tuber of 'Huayu-5' was higher than that in 'Zhongshu-19'. 'Huayu5 ' reached the highest yield when the potassium application was $159.45 \mathrm{~kg} \mathrm{ha}^{-1}$, and 'Zhongshu-19' reached the highest yield when the potassium application was $281.4 \mathrm{~kg} \mathrm{ha}^{-1}$. This study indicated that genetic variation for $\mathrm{K}$ utilization efficiency existed among 20 genotypes, and yield in low $\mathrm{K}$ application and relative yield were suitable criteria for screening $\mathrm{K}$ utilization efficiency genotypes.
\end{abstract}

Keywords: potato; potassium efficiency; potassium distribution; sucrose

\section{Introduction}

Potassium (K), which accumulates to $10 \%$ of plant dry weight (Adams and Shin, 2014), has many functions in plant growth, such as the smooth progression of cell division and growth (Anschütz et al., 2014), leaf expansion and root elongation (Jordan-Meille and Pellerin, 2004; Song et al., 2017), transportation of carbohydrates, disease resistance and drought tolerance (Saha et al., 2016). The fraction of soil K that can be absorbed directly by plants is generally quite low $(0.1-0.2 \%)$ because most soil $\mathrm{K}$ forms insoluble complexes

Received: 13 Dec 2020. Received in revised form: 19 Feb 2021. Accepted: 25 Feb 2021. Published online: 09 Mar 2021.

From Volume 49, Issue 1, 2021, Notulae Botanicae Horti Agrobotanici Cluj-Napoca journal will use article numbers in place of the traditional method of continuous pagination through the volume. The journal will continue to appear quarterly, as before, with four annual numbers. 
(Huo-Yan et al., 2010; Saha et al., 2016). A study showed that the soil available K in southwest China was lower than that in other regions (He et al.,2016). K is one of the principal nutrient elements required for crop growth and therefore needs to be added as fertilizer to increase the crop yield. $\mathrm{K}$ can be more easily leached from the soil than nitrogen (N) or phosphorus (P) (Neirynck et al., 1998), and most of the K applied as fertilizer is lost to the environment, where it poses threats to human and ecosystem health at local to global scales. It is necessary for us to study crop nutrient use efficiency under different environmental conditions and to identify more nutrient-efficient genotypes.

Several studies have proven genetic variations in nutrient efficiency. Variations in nutrient efficiency have been assessed among different crop species, including rice (Mohammed, 2018), wheat (Nguyen et al., 2016), and soybean (Zhou et al., 2016). Recent advances have highlighted genotypic differences in nitrogen and phosphorus use efficiency. Based on the average yield of potato varieties with and without $\mathrm{N}$ applications, Dandan et al. (2019) classified seven potato varieties into four types. Sandaña (2016) used correlation matrixbased principal component analysis (PCA) based on genotype main effects, phosphorus utilization efficiency and related traits using Statgraphics to assess potato phosphorus efficiency. To date, little focus has been directed towards K efficiency, especially in potato. Nutrient efficiency may be defined as yield per unit of fertilizer available to the crop (Moll et al., 1982). K efficiency is a criterion of genotypic tolerance of K-deficient soil and it can be quantified as the ratio of growth with a deficient and adequate $\mathrm{K}$ supply (Damon and Rengel, 2007). However, it is difficult to evaluate crop $\mathrm{K}$ efficiency because of different $\mathrm{K}$ tolerances and sensitivities in different crop genotypes.

Crops largely transport $\mathrm{K}$ from older to younger plant tissues and ensure redistribution of this ion towards growing tissues such as developing leaves and fruits. High $\mathrm{K}$ efficiency not only has great uptake and utilization ability but also reasonably redistributes $\mathrm{K}$ in all plant organs. A high $\mathrm{K}$-efficiency genotype has a better partitioning of $\mathrm{K}$ to the economic sink as well as a higher $\mathrm{K}$ concentration associated with the resourcesink relationship at different growth stages (Wang et al., 2017). A previous study reported that K-efficient rice was closely associated with high $\mathrm{K}$ translocation to functioning leaves and efficient sodium substitution in older leaves (Jia et al., 2008). Nutrient deficiency also influences biomass partitioning and nutrient allocation among crop tissues (Singh et al., 2014). Increasing nutrient application to a crop drives the production of a greater canopy biomass with the potential for higher photosynthesis. However, the relationship between $\mathrm{K}$ and potato tuber development is only partially understood; hence, this experiment determined the effect of $\mathrm{K}$ on photosynthetic products and tuber yield. Sugars perform important regulatory functions in plants, including photosynthesis and carbohydrate partitioning (Chiou and Bush, 1998; Rolland et al., 2002). In addition, $\mathrm{K}$ is necessary not only for phloem loading but also for sucrose transport in the phloem (Koch et al., 2019). Martineau et al. (2017) demonstrated that $\mathrm{K}$ deficiency significantly decreased the starch content in leaves. This will lay a foundation for further extensive mechanistic studies directly linking $\mathrm{K}$ to carbohydrates in different plant organs.

Potato is a major world food crop that has higher $\mathrm{K}$ requirements than cereals, pulses, oilseeds and other commercial crops. According to Keli et al. (2003), producing $1000 \mathrm{~kg}$ dry matter yield of potato tubers removes approximately $10 \mathrm{~kg} \mathrm{~K}$ from the soil. Indeed, the $\mathrm{K}$ concentrations in the leaves were below the threshold level of $42.3 \mathrm{~g} \mathrm{~kg}^{-1}$, which is associated with the maximum tuber yield (Reis Jr and Monnerat, 2000). $\mathrm{K}_{2} \mathrm{O}$ (270-300 $\mathrm{kg} \mathrm{ha}^{-1}$ ) produced the highest yield in potato production (Zelelew et al., 2016; Zhang et al., 2018). To reduce $\mathrm{K}$ fertilizer inputs and environmental pollution, the experiments reported here were designed to identify (1) potato genotypes with high $\mathrm{K}$ efficiency for further use in breeding, and (2) the differences in $\mathrm{K}$ and sugar distributions between high- and low-K utilization efficiency potato genotypes. 


\section{Materials and Methods}

\section{Experiment 1: genotype screening}

A genotype screening experiment was conducted in 2018 at the Institute of the Tuberous Corps Research, Southwest University, Chongqing, China $\left(29^{\circ} 768 \mathrm{~N}, 106^{\circ} 380 \mathrm{E}\right.$, and altitude $\left.241 \mathrm{~m}\right)$. In total, 20 potato genotypes or breeding lines were screened (Table 1). The experimental design was a split zone design with three replications. A pot experiment was conducted from January to May in a plastic box $(55 \times 45 \times 23 \mathrm{~cm})$ filled with nutrient-poor vermiculite, in which 5 seed tubers were planted. All plots received an application of $225 \mathrm{~kg} \mathrm{ha}^{-1}$ urea and $80 \mathrm{~kg} \mathrm{ha}^{-1}$ calcium superphosphate. Treatments consisted of two K fertilizer rates: (i) 75 $\mathrm{kg} \mathrm{ha}^{-1} \mathrm{~K}_{2} \mathrm{O}\left(\mathrm{K}_{\mathrm{L}}\right)$ and (ii) $300 \mathrm{~kg} \mathrm{ha}^{-1} \mathrm{~K}_{2} \mathrm{O}\left(\mathrm{K}_{\mathrm{H}}\right)$. Common cultivation measures were adopted during the growing season. All plant samples were harvested at the maturity stage for each genotype. Aboveground biomass, tuber yield, and $\mathrm{K}$ concentration were determined for the calculation of the related $\mathrm{K}$ efficiency parameters.

Table 1. The potato varieties in the experiment

\begin{tabular}{|c|c|c|c|}
\hline No & Variety & No & Variety \\
\hline 1 & '378711.7’ & 11 & 'S03-0452' \\
\hline 2 & '049565’ & 12 & 'Lishu-6' \\
\hline 3 & '09307-830’ & 13 & 'Anlong-5' \\
\hline 4 & '2014X3-1' & 14 & 'Qiangyu-6’ \\
\hline 5 & 'B20-7’ & 15 & ‘08CA0710’ \\
\hline 6 & 'C19' & 16 & 'Enshu78-11' \\
\hline 7 & 'S21' & 17 & 'Zhongshu-19' \\
\hline 8 & 'Huayu-5' & 18 & 'Zhengshu-5' \\
\hline 9 & 'Chuanyu-117' & 19 & 'Zaodabai' \\
\hline 10 & 'Liangshu-2' & 20 & 'Mira' \\
\hline
\end{tabular}

\section{Experiment 2: physiological responses}

In 2019, two genotypes, 'Huayu-5' (LKH, high efficiency at low K treatment) and 'Zhongshu-19' ( $\mathrm{HKH}$, high efficiency at high $\mathrm{K}$ treatment), were used in the pot experiments to examine the differences in $\mathrm{K}$ concentration, sucrose, yield, and dry weight. The selection of the two genotypes was based on screening of the tuber yield with low $\mathrm{K}$ application and relative yield among the 20 potato genotypes in 2018 . The pot size was $32 \mathrm{~cm}$ diameter by $27 \mathrm{~cm}$ tall. The ratio of soil to coconut chaff was $3: 1$. Soil in the $0-20 \mathrm{~cm}$ profile contained $26 \mathrm{mg} \mathrm{kg}^{-1}$ bicarbonate-extractable $\mathrm{K}, 44 \mathrm{mg} \mathrm{kg}^{-1}$ bicarbonate-extractable $\mathrm{P}, 6.5 \mathrm{~g} \mathrm{~kg}^{-1}$ organic matter, and a pH of 6.9. A uniform fertilizer application of $80 \mathrm{~kg} \mathrm{ha}^{-1}$ calcium superphosphate and $225 \mathrm{~kg} \mathrm{ha}^{-1}$ urea at seeding was applied. The five $\mathrm{K}$ fertilizer rates were (1) $0 \mathrm{~kg} \mathrm{ha}^{-1} \mathrm{~K}_{2} \mathrm{O}$ (K0), (2) $75 \mathrm{~kg} \mathrm{ha}^{-1} \mathrm{~K}_{2} \mathrm{O}$ (K1), (3) $150 \mathrm{~kg} \mathrm{ha}^{-1}$ $\mathrm{K}_{2} \mathrm{O}(\mathrm{K} 2)$, (4) $225 \mathrm{~kg} \mathrm{ha}^{-1} \mathrm{~K}_{2} \mathrm{O}\left(\mathrm{K} 3\right.$ ), and (5) $300 \mathrm{~kg} \mathrm{ha}^{-1} \mathrm{~K}_{2} \mathrm{O}$ (K4). One seed tuber per pot was sown. Forty pots were planted for every treatment. Plant samples were collected from three pots at 20, 40, 60, and 80 days after planting (DAP) and were separated into different organs (leaf, stem, root and tuber).

\section{Measurements}

In the two experiments, all samples were dried at $105^{\circ} \mathrm{C}$ in an oven for $30 \mathrm{~min}$ and then air-oven dried at $75^{\circ} \mathrm{C}$ until reaching a constant weight. The dried samples were ground with a cyclone mill through a 0.18 $\mathrm{mm}$ screen. Subsamples of plant materials were digested in concentrated $\mathrm{H}_{2} \mathrm{SO}_{4}$ and $\mathrm{H}_{2} \mathrm{O}_{2}$, and the $\mathrm{K}$ concentration was measured by a flame photometer (Chen and Gabelman, 1995). The sucrose and reducing sucrose contents were determined (Chi, 2007). The following parameters were calculated in terms of dry matter and the $\mathrm{K}$ concentrations in different organs: 
(1) $\mathrm{K}$ accumulation value $(\mathrm{KAV})=$ dry matter weight $\times \mathrm{K}$ concentration;

(2) K uptake efficiency $(\mathrm{KUpE})=\mathrm{KAV}$ in all organs/K applied;

(3) K utilization efficiency (KIUE) $=\mathrm{KAV}$ in all organs/dry matter weight;

(4) $\mathrm{K}$ harvest index $(\mathrm{KHI})=\mathrm{KAV}$ in tubers/KAV in all organs;

(5) Relative yield $=$ Tuber yield at low $\mathrm{K}$ level/Tuber yield at high $\mathrm{K}$ level.

\section{Statistical analysis}

Experimental data were calculated by office EXCEL 2016 software. Analysis of variance (ANOVA), mean separation and cluster analysis were performed using SPSS 19.0 software (SPSS Inc., Chicago, IL, USA). The data were analysed with one- and two-way ANOVA by Tukey's test. Cluster analysis was performed by the hierarchical cluster method with the Ward method and square Euclidean distance measure.

\section{Results}

\section{Variation of potassium uptake and utilization efficiency in potato varieties}

There were highly significant effects of $\mathrm{K}$, genotype and $\mathrm{K} \times \mathrm{G}$ interactions on tuber yield, plant and tuber $\mathrm{K}$ content, plant $\mathrm{K}$ uptake efficiency and $\mathrm{K}$ harvest index (Table 2). Potato tuber yield for the 20 genotypes ranged from 65.00 to 515.00 g plant $^{-1}$ at $\mathrm{K}_{\mathrm{L}}$ and from 50.00 to $630.00 \mathrm{~g} \mathrm{plant}^{-1}$ at $\mathrm{K}_{\mathrm{H}}$. Under the $\mathrm{K}_{\mathrm{H}}$ treatment, potato yield, tuber $\mathrm{K}$ content, KIUE and KHI were improved. There were significant increases in $\mathrm{K}$ uptake efficiency in the $\mathrm{K}_{\mathrm{L}}$ treatment compared with the $\mathrm{K}_{\mathrm{H}}$ treatment. The average yield of the 20 potato genotypes was reduced by $16.4 \%$ in the $\mathrm{K}_{\mathrm{L}}$ treatment compared with the $\mathrm{K}_{\mathrm{H}}$ treatment.

Table 2. Variation of potassium uptake and utilization efficiency in potato varieties and $\mathrm{K}$ treatments

\begin{tabular}{|c|c|c|c|c|c|c|c|}
\hline Parameter & $\mathrm{K}$ treatment & $\begin{array}{c}\text { Yield } \\
\left(\text { g plant }^{-1}\right)\end{array}$ & $\begin{array}{l}\text { Plant K content } \\
\quad\left(\text { g plant }^{-1}\right)\end{array}$ & $\begin{array}{c}\text { tuber } \mathrm{K} \\
\text { content } \\
\left(\text { g plant }^{-1}\right)\end{array}$ & $\begin{array}{c}\text { K uptake } \\
\text { efficiency (\%) }\end{array}$ & $\begin{array}{l}\text { K utilization } \\
\text { efficiency }(\%)\end{array}$ & $\begin{array}{c}\text { K harvest } \\
\text { index }\left(\mathrm{g}^{2} \cdot \mathrm{g}^{-1}\right)\end{array}$ \\
\hline \multirow[t]{2}{*}{ Range } & $\mathrm{K}_{\mathrm{L}}$ & $65.00-515.00$ & $0.14-1.95$ & $0.46-3.46$ & $48.59-268.83$ & $8.48-27.13$ & $30.84-92.22$ \\
\hline & $\mathrm{K}_{\mathrm{H}}$ & $50.00-630.00$ & $0.13-1.86$ & $0.54-5.73$ & $9.49-95.83$ & $6.73-25.02$ & $44.69-96.73$ \\
\hline \multirow[t]{2}{*}{ Average } & $\mathrm{K}_{\mathrm{L}}$ & 219.58 & 0.75 & 1.52 & 136.12 & 17.20 & 66.98 \\
\hline & $\mathrm{K}_{\mathrm{H}}$ & 262.42 & 0.61 & 1.90 & 37.57 & 17.91 & 75.19 \\
\hline \multirow[t]{2}{*}{ CV (\%) } & $\mathrm{K}_{\mathrm{L}}$ & 42.59 & 60.84 & 48.73 & 40.69 & 20.23 & 49.70 \\
\hline & $\mathrm{K}_{\mathrm{H}}$ & 53.01 & 65.47 & 55.01 & 48.02 & 22.40 & 46.65 \\
\hline \multirow[t]{3}{*}{ ANOVA } & Genotype & ** & *** & $* *$ & *** & ** & ** \\
\hline & K treatment & ** & $* *$ & ** & ** & * & ** \\
\hline & Genotype $\times \mathrm{K}$ & ** & ** & ** & ** & *** & *** \\
\hline
\end{tabular}

Two-way ANOVA was used for assessing the variations of different parameters between $\mathrm{K}$ availability (K0, K1) and genotype, and ${ }^{*},{ }^{* *}$, indicate significance at $\mathrm{P}=0.05, \mathrm{P}=0.01$, respectively. Ns; not significant using Tukey's test

\section{Cluster analysis for genotype $x$ potassium level}

Clustering of genotypes based on low $\mathrm{K}$ yield and relative yield. The clustering result indicated potato genotypes could be divided into four groups (Figure 1). In cluster I, 'S03-0452', 'Mira', 'S21', '049565', 'Enshu78-11', '2014X3-1', 'Anlong-5', 'Zhongshu-19' and 'Zaodabai' had high-tuber yield at $\mathrm{K}_{\mathrm{H}}$ treatment and low yield at $\mathrm{K}_{\mathrm{L}}$ treatment, which called $\mathrm{HKH}$ (high efficiency at high $\mathrm{K}$ application). The Clusters II, '08CA0710', '09307-830', 'B20-7' and 'Liangshu-2' had low-tuber yield both at $\mathrm{K}_{\mathrm{H}}$ and $\mathrm{K}_{\mathrm{L}}$ treatment, which called DL (low efficiency at low and high K application). In cluster III, '318711.7', 'Chuanyu-117' and 'Qiangyu-6' and high-tuber yield at $\mathrm{K}_{\mathrm{H}}$ and $\mathrm{K}_{\mathrm{L}}$ treatment, which called DH (high efficiency at low and high $\mathrm{K}$ application). In cluster IV, 'C19', 'Lishu-6', 'Huayu-5' and 'Zhengshu-5' had high-tuber yield at low K level and low-tuber yield at high $\mathrm{K}$ treatment, which called LKH (high efficiency at low K application). 


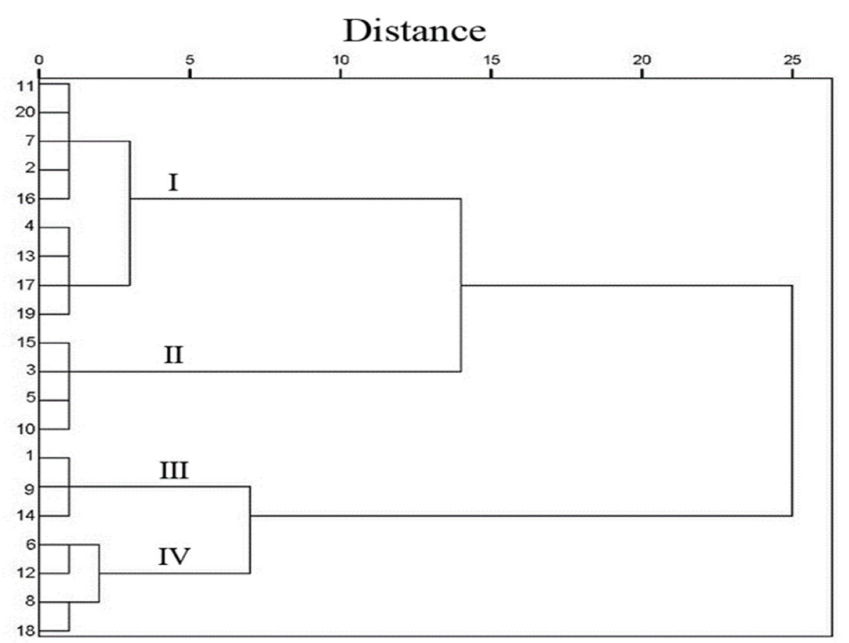

Figure 1. Ward's cluster analysis classifications of 20 potato genotypes based on screening of tuber yield at low potassium application and relative yield

\section{Changes in $K$ concentration, proportions and redistribution from various organs}

There were some remarkable differences in $\mathrm{K}$ concentration among the tissues and growth stages. At 20 and $40 \mathrm{DAP}$, the root $\mathrm{K}$ concentration did not change in response to increased $\mathrm{K}$ application. In addition, there was no significant difference in the root $\mathrm{K}$ concentration of the same genotype under different $\mathrm{K}$ treatments. At 40 DAP, the root $\mathrm{K}$ concentrations of 'Huayu-5' and 'Zhongshu-19' peaked at $\mathrm{K} 4$ and were $52.80 \mathrm{mg} \mathrm{g}^{-1}$ and $52.37 \mathrm{mg} \mathrm{g}^{-1}$, respectively. At $60 \mathrm{DAP}$, the root $\mathrm{K}$ concentration of 'Huayu- 5 ' increased with increasing $\mathrm{K}$ application and reached a maximum at K4. The change in root K concentration of 'Zhongshu-19' at 60 DAP showed a trend of first increasing and then decreasing, reaching a maximum in the $\mathrm{K} 3$ treatment. At $80 \mathrm{DAP}$, the root K concentrations of 'Huayu-5' and 'Zhongshu-19' both increased first and then decreased. It can be seen from Table 4 that with the growth and development of the potatoes, most of the root $\mathrm{K}$ concentrations showed a trend of increasing and then decreasing under the same $\mathrm{K}$ treatment. Compared with roots and leaves, stems had higher K concentrations. A lower K concentration in the stems of both varieties appeared at 20 DAP, and the $\mathrm{K}$ concentration gradually increased over time. At 60 and $80 \mathrm{DAP}$, the stem K concentration of 'Huayu- 5 ' increased with increasing $\mathrm{K}$ application. The leaf $\mathrm{K}$ concentration was higher than that in roots but lower than that in stems. The leaf $\mathrm{K}$ concentration in different potato varieties was significantly higher in the early stages of growth and development, but the leaf K concentration of 'Zhongshu-19' was significantly higher than that in the leaves of 'Huayu- 5 ' in the later stage. At 60 DAP, the leaf K concentration of 'Zhongshu-19' was the highest under the $\mathrm{K} 2$ treatment, with a content of $61.72 \mathrm{mg} \mathrm{g}^{-1}$, and 'Huayu-5' was the greatest at the $\mathrm{K} 3$ level, which was $52.75 \mathrm{mg} \mathrm{g}^{-1}$.

The accumulation of $\mathrm{K}$ in different organs is shown in Table 4 . The root $\mathrm{K}$ accumulation of 'Zhongshu$19^{\prime}$ in the K2, K3 and $\mathrm{K} 4$ treatments was $158.34,161.29$ and $160.17 \mathrm{mg}^{2}$ plant $^{-1}$, respectively. The root $\mathrm{K}$ accumulation of Zhongshu-19 was significantly higher than that of 'Huayu- 5 '. The stem $\mathrm{K}$ accumulation of Zhongshu-19 showed a trend of first increasing and then decreasing with increasing $\mathrm{K}$ application and reached a maximum in the $\mathrm{K} 2$ treatment, which was $457.35 \mathrm{mg}$ plant $^{-1}$. The stem $\mathrm{K}$ accumulation of 'Huayu- 5 ' was the lowest without $\mathrm{K}$ application and $\mathrm{K} 1$ treatment, which was 200.15 and $199.89 \mathrm{~g}$ plant $^{-1}$, respectively. The change trend of tuber $\mathrm{K}$ accumulation first increased and then decreased with increasing $\mathrm{K}$ application. 
Table 3. Difference of potassium concentration in different parts of potato varieties and $\mathrm{K}$ treatments

\begin{tabular}{|c|c|c|c|c|c|c|}
\hline \multirow{2}{*}{ Position } & \multirow{2}{*}{ Variety } & \multirow{2}{*}{ K treatment } & \multicolumn{4}{|c|}{ Potassium concentration $\left(\mathrm{mg} \cdot \mathrm{g}^{-1}\right)$} \\
\hline & & & $20 \mathrm{~d}$ & $40 \mathrm{~d}$ & $60 \mathrm{~d}$ & $80 \mathrm{~d}$ \\
\hline \multirow{10}{*}{ Root } & \multirow{5}{*}{ 'Huayu-5' } & K0 & $29.41 \pm 0.59 \mathrm{c}$ & $44.83 \pm 2.36 \mathrm{ab}$ & $38.31 \pm 1.13 \mathrm{~d}$ & $36.26 \pm 2.01 \mathrm{~d}$ \\
\hline & & K1 & $29.40 \pm 0.16 c$ & $40.92 \pm 0.83 \mathrm{~b}$ & $44.02 \pm 6.27 \mathrm{~cd}$ & $38.96 \pm 1.29 \mathrm{~d}$ \\
\hline & & K2 & $34.20 \pm 1.82 \mathrm{~b}$ & $43.16 \pm 2.32 b$ & $46.22 \pm 4.08 \mathrm{bcd}$ & $42.09 \pm 1.98 \mathrm{~cd}$ \\
\hline & & K3 & $28.52 \pm 0.93 c$ & $44.56 \pm 0.12 \mathrm{ab}$ & $49.38 \pm 1.10 \mathrm{abc}$ & $54.67 \pm 2.29 a$ \\
\hline & & K4 & $33.65 \pm 0.50 \mathrm{~b}$ & $52.80 \pm 4.87 \mathrm{a}$ & $50.42 \pm 1.53 \mathrm{abc}$ & $42.35 \pm 1.02 \mathrm{~cd}$ \\
\hline & \multirow{5}{*}{ 'Zhongshu-19' } & K0 & $37.20 \pm 0.13 \mathrm{a}$ & $38.88 \pm 0.71 \mathrm{~b}$ & $46.11 \pm 1.11 \mathrm{bcd}$ & $46.95 \pm 0.95 b c$ \\
\hline & & K1 & $34.41 \pm 0.41 \mathrm{~b}$ & $46.02 \pm 0.94 \mathrm{ab}$ & $48.56 \pm 1.22 \mathrm{abc}$ & $52.84 \pm 2.65 \mathrm{ab}$ \\
\hline & & K2 & $39.75 \pm 0.67 a$ & $39.60 \pm 2.88 \mathrm{~b}$ & $55.12 \pm 2.91 \mathrm{ab}$ & $51.55 \pm 1.55 \mathrm{ab}$ \\
\hline & & K3 & $33.93 \pm 0.35 b$ & $44.71 \pm 2.35 \mathrm{ab}$ & $57.08 \pm 2.37 \mathrm{a}$ & $50.70 \pm 0.88 \mathrm{ab}$ \\
\hline & & K4 & $33.49 \pm 0.73 b$ & $52.37 \pm 2.50 \mathrm{a}$ & $46.12 \pm 1.62 \mathrm{bcd}$ & $46.85 \pm 2.82 \mathrm{bc}$ \\
\hline \multirow{10}{*}{ Stem } & \multirow{5}{*}{ 'Huayu-5' } & K0 & $83.69 \pm 4.04 \mathrm{abc}$ & $102.87 \pm 3.51 \mathrm{a}$ & $89.76 \pm 5.85 \mathrm{~d}$ & $84.51 \pm 2.95 \mathrm{~d}$ \\
\hline & & K1 & $85.27 \pm 2.35 \mathrm{abc}$ & $89.61 \pm 2.31 \mathrm{bc}$ & $88.35 \pm 6.04 \mathrm{~d}$ & $95.49 \pm 2.64 \mathrm{~cd}$ \\
\hline & & K2 & $84.58 \pm 3.02 \mathrm{abc}$ & $102.72 \pm 1.38 \mathrm{a}$ & $104.70 \pm 1.40 \mathrm{abc}$ & $114.64 \pm 2.04 \mathrm{ab}$ \\
\hline & & K3 & $92.84 \pm 2.21 \mathrm{a}$ & $99.69 \pm 4.37 \mathrm{a}$ & $91.31 \pm 0.85 \mathrm{~d}$ & $97.15 \pm 1.01 \mathrm{c}$ \\
\hline & & K4 & $82.12 \pm 0.33 b c$ & $96.54 \pm 2.08 \mathrm{ab}$ & $88.87 \pm 2.74 \mathrm{~d}$ & $83.64 \pm 3.63 \mathrm{~d}$ \\
\hline & \multirow{5}{*}{ 'Zhongshu-19' } & K0 & $89.39 \pm 0.42 \mathrm{ab}$ & $105.02 \pm 1.31 \mathrm{a}$ & $100.86 \pm 5.40 \mathrm{bcd}$ & $119.34 \pm 1.81 \mathrm{a}$ \\
\hline & & K1 & $79.38 \pm 1.22 \mathrm{c}$ & $99.43 \pm 4.011 \mathrm{a}$ & $116.07 \pm 2.21 \mathrm{a}$ & $98.26 \pm 6.90 c$ \\
\hline & & K2 & $80.72 \pm 5.54 \mathrm{bc}$ & $96.81 \pm 1.10 \mathrm{ab}$ & $100.82 \pm 2.17 \mathrm{bcd}$ & $117.74 \pm 2.75 \mathrm{ab}$ \\
\hline & & K3 & $87.36 \pm 0.28 \mathrm{abc}$ & $98.03 \pm 1.02 \mathrm{ab}$ & $112.15 \pm 1.04 \mathrm{ab}$ & $100.97 \pm 3.20 c$ \\
\hline & & $\mathrm{K} 4$ & $84.64 \pm 0.19 \mathrm{abc}$ & $86.17 \pm 0.55 c$ & $98.84 \pm 4.22 \mathrm{~cd}$ & $107.12 \pm 3.32 \mathrm{bc}$ \\
\hline \multirow{10}{*}{ Leaf } & \multirow{5}{*}{ 'Huayu-5' } & K0 & $34.13 \pm 2.04 \mathrm{~cd}$ & $50.66 \pm 1.93 \mathrm{~cd}$ & $47.26 \pm 1.71 \mathrm{~b}$ & $43.51 \pm 3.16 \mathrm{e}$ \\
\hline & & K1 & $32.30 \pm 0.83 \mathrm{~d}$ & $52.32 \pm 1.34 \mathrm{bcd}$ & $48.98 \pm 1.14 \mathrm{ab}$ & $46.52 \pm 1.12 \mathrm{de}$ \\
\hline & & K2 & $32.82 \pm 2.33 \mathrm{~d}$ & $50.70 \pm 0.90 \mathrm{~cd}$ & $47.4 \pm 5.093 \mathrm{~b}$ & $50.62 \pm 2.03 \mathrm{~cd}$ \\
\hline & & K3 & $39.03 \pm 2.25 \mathrm{ab}$ & $51.08 \pm 2.73 \mathrm{~cd}$ & $52.75 \pm 1.90 \mathrm{ab}$ & $53.75 \pm 2.36 \mathrm{bc}$ \\
\hline & & K4 & $38.81 \pm 0.30 \mathrm{ab}$ & $49.80 \pm 1.39 \mathrm{~d}$ & $47.90 \pm 3.00 \mathrm{ab}$ & $35.89 \pm 1.08 \mathrm{f}$ \\
\hline & \multirow{5}{*}{ 'Zhongshu-19' } & K0 & $41.22 \pm 0.22 \mathrm{a}$ & $56.49 \pm 2.16 \mathrm{abc}$ & $60.91 \pm 2.51 \mathrm{ab}$ & $61.26 \pm 0.19 a$ \\
\hline & & K1 & $40.45 \pm 0.26 \mathrm{ab}$ & $56.38 \pm 0.81 \mathrm{abc}$ & $54.13 \pm 1.02 \mathrm{ab}$ & $58.18 \pm 2.11 \mathrm{ab}$ \\
\hline & & $\mathrm{K} 2$ & $38.54 \pm 0.14 a b c$ & $59.39 \pm 2.48 \mathrm{a}$ & $61.72 \pm 0.43 a$ & $54.08 \pm 1.03 \mathrm{bc}$ \\
\hline & & K3 & $35.99 \pm 0.22 \mathrm{bcd}$ & $57.90 \pm 1.35 \mathrm{ab}$ & $52.74 \pm 9.54 \mathrm{ab}$ & $50.20 \pm 1.86 \mathrm{~cd}$ \\
\hline & & K4 & $37.61 \pm 1.08 \mathrm{abc}$ & $56.72 \pm 0.62 \mathrm{abc}$ & $55.47 \pm 3.66 \mathrm{ab}$ & $58.79 \pm 1.73 \mathrm{ab}$ \\
\hline
\end{tabular}

Genotypes with different letters are significantly different (Tukey's test, $\mathrm{p}<0.05$ )

The tuber $\mathrm{K}$ accumulation of 'Huayu- 5 ' maintained the largest accumulation in the $\mathrm{K} 2$ treatment (1124.10 $\left.\mathrm{mg} \mathrm{plant}^{-1}\right)$ and the lowest accumulation in the K0 treatment (453.69 $\mathrm{mg}$ plant $^{-1}$ ). The tuber $\mathrm{K}$ accumulation of 'Zhongshu-19' was significantly different among the treatments. The highest tuber $\mathrm{K}$ accumulation appeared in the $\mathrm{K} 3$ treatment, which was $1847.78 \mathrm{mg} \cdot p$ lant ${ }^{-1}$, and the lowest tuber $\mathrm{K}$

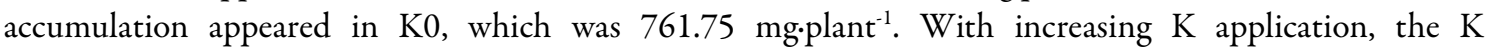
accumulation of the whole plant showed a trend of increasing first and then decreasing. The $\mathrm{K}$ accumulation of 'Huayu-5' at the K1 and K2 levels was respectively $64.63 \%$ and $98.78 \%$ higher than that with no K application. The K of the whole 'Zhongshu-19' plant in the K2 treatment was $29.57 \%$ higher than that in the K1 treatment. At 80 DAP, the tuber K proportion of the total plants was $55.18-72.32 \%$ and $54.52-67.39 \%$ for 'Huayu-5' and 'Zhonshu-19' with different K applications, respectively.

The accumulation and distribution rate of $\mathrm{K}$ in various organs of the potato plants were tuber $>$ stem $>$ leaf $>$ root (Figure 2). K had no significant effect on the root $\mathrm{K}$ distribution rate of 'Zhongshu-19', and its range was 5.04-7.39\%. However, there was a relatively large effect on the root $\mathrm{K}$ distribution of 'Huayu5', and its range was $1.66-4.89 \%$. Under different $\mathrm{K}$ applications, the $\mathrm{K}$ distribution rate of 'Huayu-5' tubers initially increased and then decreased. The highest $\mathrm{K}$ distribution rate appeared in the $\mathrm{K} 1$ treatment $(72.32 \%)$, and the lowest $\mathrm{K}$ distribution rate was in the non-K treatment (55.18\%). The $\mathrm{K}$ distribution rate in the tubers of 'Zhongshu-19' increased with increasing K application. The K distribution rate of the stems was opposite to that of the tubers, indicating that $\mathrm{K}$ can promote the transfer of nutrition from potato stems to tubers. 
Table 4. Potassium accumulation and distribution of different potato varieties

\begin{tabular}{|c|c|c|c|c|c|c|}
\hline Variety & $\begin{array}{c}\mathrm{K} \\
\text { treatment }\end{array}$ & $\begin{array}{c}\text { Root } \\
(\mathrm{mg})\end{array}$ & $\begin{array}{c}\text { Stem } \\
(\mathrm{mg})\end{array}$ & $\begin{array}{c}\text { Leaf } \\
(\mathrm{mg})\end{array}$ & $\begin{array}{c}\text { Tuber } \\
(\mathrm{mg})\end{array}$ & $\begin{array}{c}\text { Total } \\
(\mathrm{mg})\end{array}$ \\
\hline \multirow{4}{*}{ 'Huayu-5' } & $\mathrm{K} 0$ & $32.93 \pm 4.18 \mathrm{~cd}$ & $200.15 \pm 18.47 \mathrm{~d}$ & $132.68 \pm 17.37 \mathrm{c}$ & $453.69 \pm 72.05 \mathrm{f}$ & $819.44 \pm 107.72 \mathrm{e}$ \\
\cline { 2 - 6 } & $\mathrm{K} 1$ & $22.17 \pm 1.63 \mathrm{~d}$ & $199.89 \pm 10.34 \mathrm{~d}$ & $150.39 \pm 14.37 \mathrm{bc}$ & $973.05 \pm 45.57 \mathrm{~cd}$ & $1345.5 \pm 60.09 \mathrm{~cd}$ \\
\cline { 2 - 7 } & $\mathrm{K} 2$ & $39.44 \pm 3.05 \mathrm{~cd}$ & $306.64 \pm 19.22 \mathrm{abcd}$ & $156.67 \pm 6.55 \mathrm{abc}$ & $1124.1 \pm 49.99 \mathrm{c}$ & $1626.85 \pm 34.41 \mathrm{bc}$ \\
\cline { 2 - 7 } & $\mathrm{K} 3$ & $59.63 \pm 3.7 \mathrm{~cd}$ & $245.92 \pm 31.47 \mathrm{~cd}$ & $148.02 \pm 23.88 \mathrm{bc}$ & $767.24 \pm 66.8 \mathrm{de}$ & $1220.8 \pm 101.41 \mathrm{~d}$ \\
\cline { 2 - 7 } & $\mathrm{K} 4$ & $39.13 \pm 2.56 \mathrm{~cd}$ & $269.16 \pm 32.95 \mathrm{bcd}$ & $119.77 \pm 12.38 \mathrm{c}$ & $597.74 \pm 46.72 \mathrm{ef}$ & $1025.8 \pm 15.56 \mathrm{de}$ \\
\hline \multirow{4}{*}{\begin{tabular}{c} 
Zhonshu- \\
\cline { 2 - 7 }
\end{tabular}} & $\mathrm{K} 0$ & $70.69 \pm 5.61 \mathrm{bc}$ & $336.52 \pm 65.79 \mathrm{abcd}$ & $231.12 \pm 18.79 \mathrm{abc}$ & $761.15 \pm 30.69 \mathrm{de}$ & $1399.48 \pm 100.23 \mathrm{~cd}$ \\
\cline { 2 - 7 } & $\mathrm{K} 1$ & $136.37 \pm 2.12 \mathrm{a}$ & $373.62 \pm 24.09 \mathrm{abcd}$ & $283.84 \pm 5.22 \mathrm{ab}$ & $1063.65 \pm 38.58 \mathrm{c}$ & $1857.47 \pm 59.81 \mathrm{~b}$ \\
\cline { 2 - 7 } & $\mathrm{K} 3$ & $158.34 \pm 17.53 \mathrm{a}$ & $457.35 \pm 120.5 \mathrm{a}$ & $215.94 \pm 17.96 \mathrm{abc}$ & $1576.36 \pm 33.16 \mathrm{~b}$ & $2407.99 \pm 66.01 \mathrm{a}$ \\
\cline { 2 - 7 } & $\mathrm{K} 4$ & $161.29 \pm 8.19 \mathrm{a}$ & $436.37 \pm 19.22 \mathrm{ab}$ & $296.79 \pm 117.33 \mathrm{a}$ & $1847.78 \pm 162.85 \mathrm{a}$ & $2742.22 \pm 203.78 \mathrm{a}$ \\
\hline
\end{tabular}

Genotypes with different letters are significantly different (Tukey's test, $\mathrm{p}<0.05$ )

'Huayu-5'

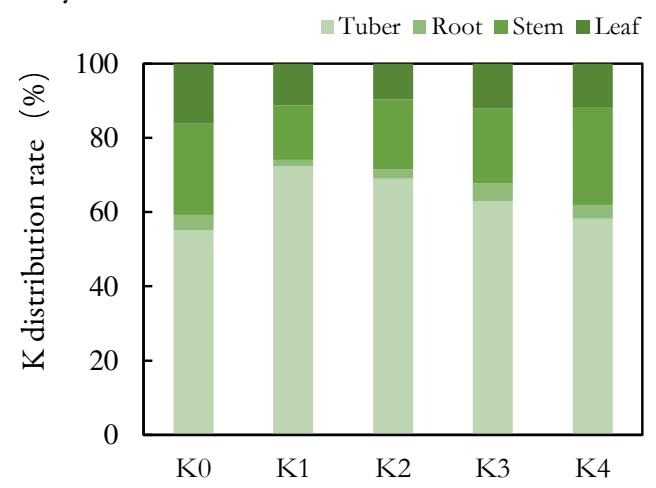

'Zhongshu-19'

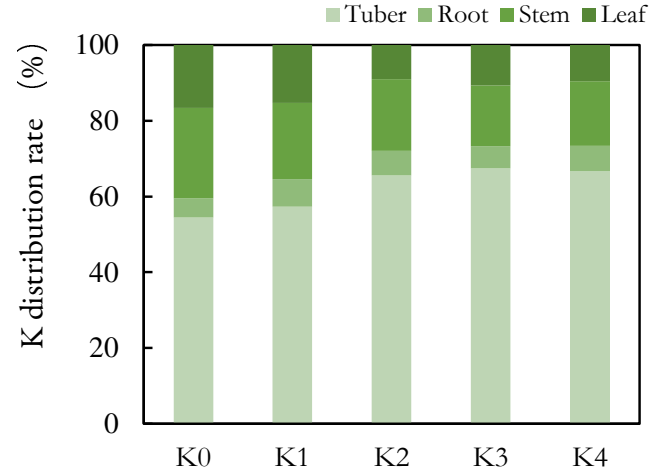

Figure 2. Potassium application on the $\mathrm{K}$ distribution rate in potato plant

\section{Differences in sucrose and reducing sucrose content between different K-efficiency varieties}

Figure 3 shows that the average sucrose content in the leaves of 'Zhongshu-19' was not statistically different among the K applications. The maximum sucrose content of 'Zhongshu-19' was $5.79 \mathrm{mg} \mathrm{g}^{-1}$ in the K0 treatment, and the smallest was $1.27 \mathrm{mgg}^{-1}$ in the $\mathrm{K} 3$ treatment. The sucrose content in the leaves of Huayu- 5 increased with increasing Kapplication and reached the highest level of $13.97 \mathrm{mg} \mathrm{g}^{-1}$ in the $\mathrm{K} 4$ treatment. With increasing Kapplication rate, the sucrose content in the tubers decreased from 15.61 to $6.43 \mathrm{mgg}^{-1}$ in Huayu- 5 and from 9.42 to $4.41 \mathrm{mgg}^{-1}$ in ' $\mathrm{Zhongsh}^{-}$ 19'. The sucrose content of 'Huayu-5' tubers was higher than that of the 'Zhongshu-19' tubers at the same K treatment. This shows that the content of tuber sucrose has an inevitable relationship with potato $\mathrm{K}$.
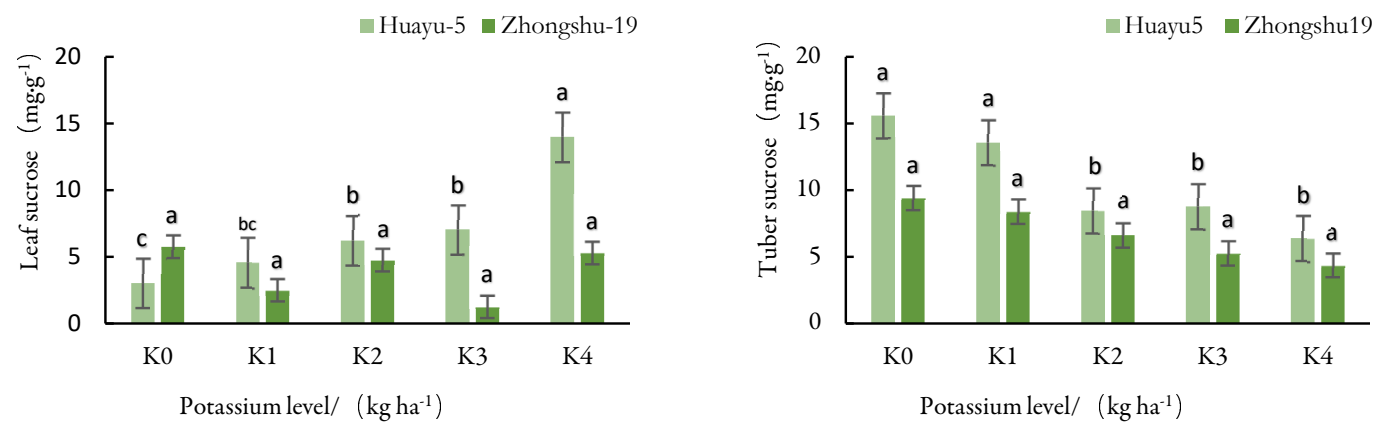

Figure 3. Differences of sucrose in different genotypes of potato

Different letters on each column are significantly difference at the $5 \%$ level by Tukey's test among potato varieties 
There were significant differences between the two potato genotypes in terms of reducing sugars in leaves and tubers (Figure 4). In the K0 treatment, 'Zhongshu-19' had the highest reducing sugars in the leaves and tubers, and its contents were $25.44 \mathrm{mg} \mathrm{g}^{-1}$ and $29.42 \mathrm{mg} \mathrm{g}^{-1}$, respectively. With increasing $\mathrm{K}$ application, the reducing sugar content in the leaves and tubers of 'Zhongshu-19' gradually decreased. K can promote the conversion of reducing sugars and reduce their accumulation in leaf cells. However, the reducing sugar content in the leaves and tubers of 'Huayu- 5 ' increased first and then decreased with increasing $\mathrm{K}$ application. The reducing sugar content of the leaves reached the highest level of $29.32 \mathrm{mg} \mathrm{g}^{-1}$ in the $\mathrm{K} 1$ treatment. The changing trend of reducing sugar content in the tubers increased slowly with increasing $\mathrm{K}$ application and decreased after the $\mathrm{K} 3$ treatment.
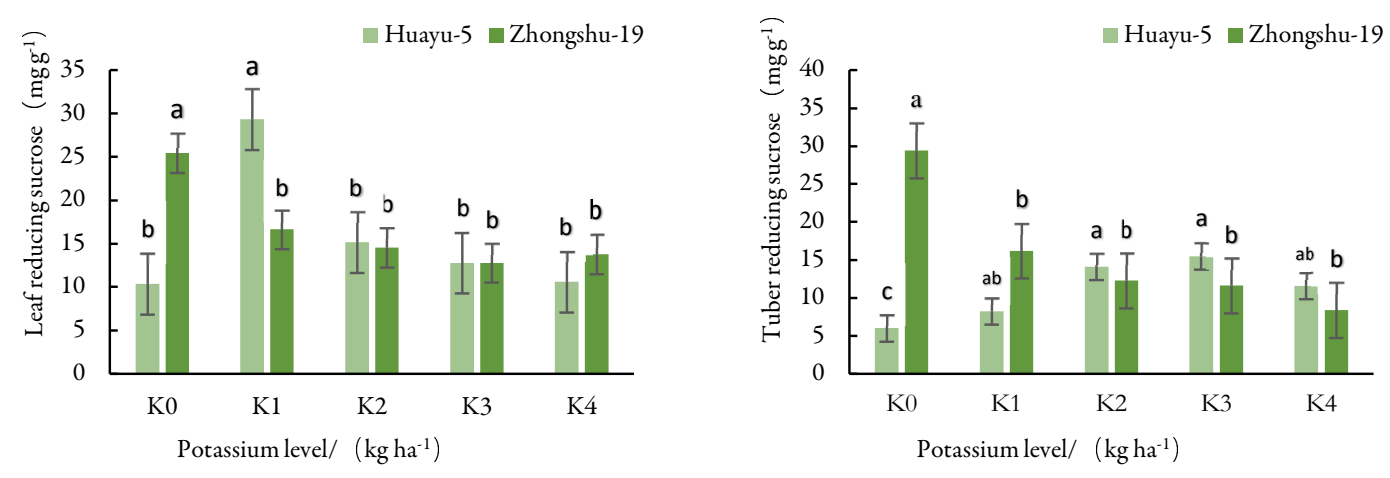

Figure 4. Differences of reducing sucrose in different genotypes of potato

Different letters on each column are significantly difference at the $5 \%$ level Tukey's test among potato varieties

\section{Regression relationship between potassium supply level and potato yield}

To determine the optimum K application of 'Huayu-5' and 'Zhongshu-19', tuber yield data were evaluated by the binary equation (Figure 5). The highest yield of 'Huayu-5' was $181.37 \mathrm{~g}$ plant ${ }^{-1}$, which was obtained from the application of $150 \mathrm{~kg} \mathrm{ha}^{-1}$. However, a further increase in the $\mathrm{K}$ rate caused the yield of 'Huayu- 5 ' to decrease. With K fertilizer application between 0 and $225 \mathrm{~kg} \mathrm{ha}^{-1}$, the yield of 'Zhongshu-19' increased substantially. At the highest $\mathrm{K}$ application rate $\left(300 \mathrm{~kg} \mathrm{ha}^{-1}\right)$, no further yield increase occurred. 'Huayu-5' reached the highest yield when $\mathrm{K}$ application was $159.45 \mathrm{~kg} \mathrm{ha}^{-1}$, and 'Zhongshu-19' reached the highest yield when $\mathrm{K}$ application was $281.4 \mathrm{~kg} \mathrm{ha}^{-1}$.
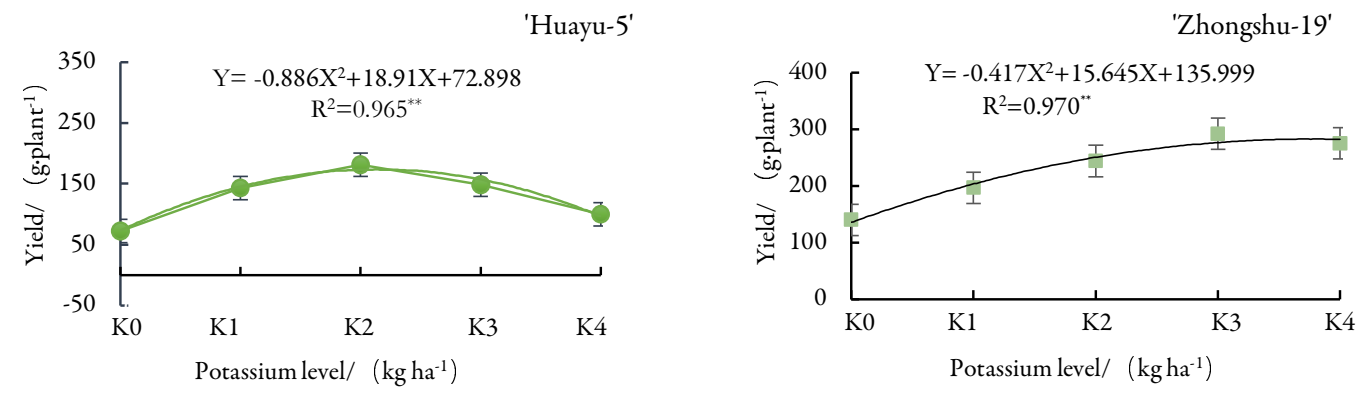

Figure 5. Effect of $\mathrm{K}$ fertilization on total tuber yield 


\section{Discussion}

\section{$G$ Genetic variations in potassium utilization efficiency and $K$ selection criteria}

The pot experiments showed that genetic variation in $\mathrm{K}$ nutrient uptake and use efficiency existed among different potato genotypes. Several studies have identified genetic variations of nutrient efficiency in different crops (wheat: Woodend and Glass, 1993; maize: Duvick, 2005; sweet potato: Wang et al., 2017). Genetic engineering and conventional breeding are crucial strategies to increase crop yields and nutrient use efficiency. In addition, the criteria are very important for the selection of genotypes with high nutrition efficiency. Previous studies of access KUE always emphasize K deficiency tolerance, which is K uptake and yield per unit of $\mathrm{k}$ taken up. To date, little focus has been directed towards crop nutrition sensitivity, which represents the change ratio of yield with increasing nutrition application. The Michaelis-Menten equation is a suitable method because it obviously shows the highest yield, the optimum nutrition application and the change in yield (Greenwood et al., 2005). However, obtaining suitable measures of the parameters requires experiments with at least six different K levels, which greatly reduces the number of genotypes that can be tested (Greenwood et al., 2006). To maximize the screening of genotypes for K response, trials usually include only a few $\mathrm{K}$ treatments and typically no more than two. According to previous studies, most potato cultivars have the highest yield at 270-300 $\mathrm{kg} \mathrm{ha}^{-1} \mathrm{~K}_{2} \mathrm{O}$ application (Zelelew et al., 2016; Zhang et al., 2018). This study chose $300 \mathrm{~kg} \mathrm{ha}^{-1} \mathrm{~K}_{2} \mathrm{O}$ as the high potassium treatment. Identifying tolerant and sensitive genotypes using different parameters, such as relative growth rate reduction (RGRRED) and use efficiency (UE), is expected to give different outputs (Mohammed, 2018). Therefore, the selection criteria in this study based on screening of tuber yield at low K application and relative yield can: (1) compare the tuber yield per plant in the 20 varieties (lines) studied under low K stress and (2) compare the change in tuber weight per plant under low K stress and high K application.

\section{Kportioning and translocation}

Generally, research on $\mathrm{K}$ efficiency has mostly focused on $\mathrm{K}$ uptake or utilization efficiency, which are essential for the selection of K high-efficiency crops (Woodend and Glass, 1993; Guoping et al., 1999; Bilal et al., 2019). However, the redistribution and accumulation abilities of $\mathrm{K}$ are both important parameters in assessing the $\mathrm{K}$ efficiency of crops (Wang et al., 2017). In this study, the $\mathrm{K}$ ion concentration was different among the four stages in roots, stems and leaves. Koch et al. (2019) found that the leaves, tubers and roots of $\mathrm{K}$-deficient plants had significantly lower K concentrations than those of K-sufficient plants. Even in fertilized fields, rapid $\mathrm{K}$ uptake by plants can lead to $\mathrm{K}$ shortages in the root environment, particularly in the early stage (Kellermeier et al., 2013). The data reported here were consistent with the observation that the $\mathrm{K}$ concentration at $20 \mathrm{DAP}$ was lower than that at $40 \mathrm{DAP}$. This phenomenon was particularly obvious in the leaves, which may be caused by them being at the distal end of potassium transportation and the fast expansion of the leaves in the early stage. Better translocation of $\mathrm{K}$ into different organs and a greater capacity to maintain the cytosolic $\mathrm{K}$ concentration within optimal ranges are the main mechanisms underlying $\mathrm{K}$ utilization efficiency (Rengel and Damon, 2008). The main assimilation product from photosynthesis in potato, sucrose, is transported from the aboveground biomass to the tubers through the phloem and then decomposed into hexoses in the tubers to provide the energy and carbon skeletons required for cell division and storage tuber bulking. $\mathrm{K}$, as the most abundant inorganic cation in phloem vessels, has an additional function in counterbalancing mobile anions in the phloem (Zörb et al., 2014). In this study, the K concentration in the phloem was higher than that in the leaves and roots. Partitioning of dry matter to the tubers was markedly reduced by $\mathrm{K}$ deficiency (Jenkins and Mahmood, 2003). This study showed that low $\mathrm{K}$ leads to a decrease in the ratio of $\mathrm{K}$ accumulation and distribution in potato tubers, and too high $\mathrm{K}$ application will also decrease the ratio of $\mathrm{K}$ accumulation. The $\mathrm{K}$ distribution ratio in seeds of the $\mathrm{K}$-efficient genotype were higher than that of the K-inefficient genotype (Liu et al., 2019). In this study, the greatest K distribution ratio of 'Huayu-5' appeared in the $\mathrm{K} 1$ treatment (72.32\%), and the greatest $\mathrm{K}$ distribution ratio of 'Zhongshu-19' appeared in the 
$\mathrm{K} 3$ treatment $(67.39 \%)$. The $\mathrm{K}$ distribution ratio may be of crucial importance for high $\mathrm{K}$ use efficiency. To improve $\mathrm{K}$ use efficiency and reduce fertilizer input, study should focus on how to reduce $\mathrm{K}$ distribution ratio in fruit.

\section{Sucrose and reducing sucrose accumulation in tuber and leaf}

Carbohydrates formed by photosynthesis play an important role in fruit production since they are not only raw materials for fruit growth but also major determinants of fruit quality (Georgelis et al., 2004; Keller et al., 2008). Soluble sugar content is positively correlated with soil $\mathrm{K}$, so increasing the supply of $\mathrm{K}$ increases sugar accumulation (Zushi and Matsuzoe, 1998); additionally, $\mathrm{K}$ is beneficial for increasing the dry matter content and improving fruit quality under drought stress (Mohammed, 2018). Therefore, increased K could lead to increased sucrose in the leaves, loading it in the phloem and transporting it to the roots for storage as starch, enhancing the yield of root crops (Omondi et al., 2020). In this study, the sucrose content of 'Huayu-5' in the leaves significantly declined as the concentration of $\mathrm{K}$ in the soil increased. These findings are congruent with those reported earlier by Omondi et al. (2020). However, the sucrose content of 'Zhongshu-19' in the leaves was not significantly different under the different $\mathrm{K}$ treatments. Sucrose in the tuber significantly declined with increasing $\mathrm{K}$ application in both genotypes. One possible explanation may be that K promotes the conversion of sucrose into starch. At the same K treatment, the tuber sucrose of 'Huayu-5' was higher than in 'Zhongshu-19', which was a difference in KUE. A suitable amount of K applied during the growing season is an efficient cultivation measure for increasing yield, as it promotes the transport of photo-assimilates from the leaves down to the storage roots (Du et al., 2020).

\section{Conclusions}

In conclusion, the present results demonstrated genetic variation difference in tuber yield, plant and tuber K content, plant K uptake efficiency and $\mathrm{K}$ harvest index. Based on the tuber yield with low Kapplication and relative yield, twenty potato genotypes could be classified into four types: $\mathrm{DH}$ (high efficiency at low and high K application), LKH (high efficiency at low K application), HKH (high efficiency at high K application) and DL (low efficiency at low and high K application). Low K and high efficiency ('Huayu-5') and high K and high efficiency ('Zhongshu-19') had significant differences in K distribution in different positions. Increasing $\mathrm{K}$ application decreased the tuber sucrose content in both cultivars.

\section{Authors' Contributions}

Conceptualization: CL; Funding acquisition: $\mathrm{CL}$ and XL; Investigation: ZD, JY and HH; Data curation: ZD and JY; Visualization: ZD and YC; Writing-original draft: ZD; Writing-review and editing: CL, JW, XL and XY. All authors read and approved the final manuscript.

\section{Acknowledgements}

This work was supported by Chongqing Science and Technology Bureau (Grant No. cstc2019jscxgksbX0157 and cstc2019jscx-msxmX0326).

\section{Conflict of Interests}

The authors declare that there are no conflicts of interest related to this article. 


\section{References}

Adams E, Shin R (2014). Transport, signaling, and homeostasis of potassium and sodium in plants. Journal of Integrative Plant Biology 56(3):231-249. https://doi.org/10.1111/jipb.12159

Anschütz U, Becker D, Shabala S (2014). Going beyond nutrition: Regulation of potassium homoeostasis as a common denominator of plant adaptive responses to environment. Journal of Plant Physiology 171(9):670-687. https://doi.org/10.1016/j.jplph.2014.01.009

Bilal HM, Aziz T, Maqsood MA, Farooq M (2019). Grain phosphorus and phytate contents of wheat genotypes released during last 6 decades and categorization of selected genotypes for phosphorus use efficiency. Archives of Agronomy and Soil Science 65(6):727-740. https://doi.org/10.1080/03650340.2018.1521957

Chen J, Gabelman WH (1995). Isolation of tomato strains varying in potassium acquisition using a sand-zeolite culture system. Plant and Soil 176(1): 65-70. https://doi.org/10.1007/BF00017676

Chi Z (2007). Regulation of starch-sugar metabolism via repression of acid invertase in potato tubers. PhD Thesis, Huazhong Agricultural University.

Chiou T-J, Bush DR (1998). Sucrose is a signal molecule in assimilate partitioning. Proceedings of the National Academy of Sciences 95(8):4784-4788. https://doi.org/10.1073/pnas.95.8.4784

Damon PM, Rengel Z (2007). Wheat genotypes differ in potassium efficiency under glasshouse and field conditions. Australian Journal of Agricultural Research 58(8):816-825. https://doi.org/10.1071/AR06402

Dandan H, Liguo J, Yonglin Q, Mingshou F (2019). Classification of potato cultivars by their nitrogen use efficiency. Acta Agronomica Sinica 1:17. https://doi.org/10.3724/SP.J.1006.2019.84059

Du F, Liu H, Yin X, Zhao Q, Shi C (2020). Potassium-mediated regulation of sucrose metabolism and storage root formation in sweet potato. Archives of Agronomy and Soil Science 1-11. https://doi.org/10.1080/03650340.2020.1751824

Duvick DN (2005). The contribution of breeding to yield advances in maize (Zea mays L.). Advances in Agronomy 86:83145. https://doi.org/10.1016/S0065-2113(05)86002-X

Georgelis N, Scott J, Baldwin E (2004). Relationship of tomato fruit sugar concentration with physical and chemical traits and linkage of RAPD markers. Journal of the American Society for Horticultural Science 129(6):839-845. https://doi.org/10.21273/JASHS.129.6.0839

Greenwood DJ, Stellacci AM, Meacham MC, Broadley MR, White PJ (2005). Phosphorus response components of different Brassica oleracea genotypes are reproducible in different environments. Crop Science 45(5):17281735. https://doi.org/10.2135/cropsci2004.0484

Greenwood DJ, Stellacci AM, Meacham MC, Mead A, Broadley MR, White PJ (2006). Relative values of physiological parameters of $\mathrm{P}$ response of different genotypes can be measured in experiments with only two P treatments. Plant and Soil 281(1-2): 159-172. https://doi.org/10.1007/s11104-005-4082-6

Guoping Z, Jingxing C, Tirore EA (1999). Genotypic variation for potassium uptake and utilization efficiency in wheat. Nutrient Cycling in Agroecosystems 54(1):41-48. https://doi.org/10.1023/A:1009708012381

He P, Yang L, Xu X, Zhao S, Chen F, Li S, ... Johnston AM (2015). Temporal and spatial variation of soil available potassium in China (1990-2012). Field Crops Research 173:49-56. https://doi.org/10.1016/j.fcr.2015.01.003

$\mathrm{Hu}$ W, Coomer TD, Loka DA, Oosterhuis DM, Zhou Z (2017). Potassium deficiency affects the carbon-nitrogen balance in cotton leaves. Plant Physiology and Biochemistry 115: 408-417. https://doi.org/10.1016/j.plaphy.2017.04.005

Huo-Yan W, Jian-Min Z, Chang-Wen D, Xiao-Qin C (2010). Potassium fractions in soils as affected by monocalcium phosphate, ammonium sulfate, and potassium chloride application. Pedosphere 20(3):368-377. https://doi.org/10.1016/S1002-0160(10)60026-4

Jenkins PD, Mahmood S (2003). Dry matter production and partitioning in potato plants subjected to combined deficiencies of nitrogen, phosphorus and potassium. Annals of Applied Biology 143(2):215-229. https://doi.org/10.1111/j.1744-7348.2003.tb00288.x

Jia Y, Yang X, Islam E, Feng Y (2008). Effects of potassium deficiency on chloroplast ultrastructure and chlorophyll fluorescence in inefficient and efficient genotypes of rice. Journal of Plant Nutrition 31(12):2105-2118. https://doi.org/10.1080/01904160802459625

Jordan-Meille L, Pellerin S (2004). Leaf area establishment of a maize (Zea mays L.) field crop under potassium deficiency. Plant \& Soil 265(1-2):75-92. https://doi.org/10.1007/s11104-005-0695-Z 
Keli L, Baolin Z, Julin G, Jinhua S (2003). Potassium absorption, accumulation and distribution of potato under dry farming. Chinese Potato Journal (6):331-335.

Keller M, Smithyman RP, Mills LJ (2008). Interactive effects of deficit irrigation and crop load on Cabernet Sauvignon in an arid climate. American Journal of Enology and Viticulture 59(3):221-234.

Kellermeier F, Chardon F, Amtmann A (2013). Natural Variation of Arabidopsis Root Architecture Reveals Complementing Adaptive Strategies to Potassium Starvation. Plant Physiology 161(3):14211432. https://doi.org/10.1104/pp.112.211144

Koch M, Busse M, Naumann M, Jákli B, Smit I, Cakmak I, Hermans C, Pawelzik E (2019). Differential effects of varied potassium and magnesium nutrition on production and partitioning of photoassimilates in potato plants. Physiologia Plantarum 166(4):921-935. https://doi.org/10.1111/ppl.12846

Liu C, Tu B, Wang X, Jin J, Li Y, Zhang Q, ... Ma B (2019). Potassium translocation combined with specific root uptake is responsible for the high potassium efficiency in vegetable soybean. Crop and Pasture Science 70(6):516-525. https://doi.org/10.1071/CP19042

Martineau E, Domec J-C, Bosc A, Dannoura M, Gibon Y, Bénard C, Jordan-Meille L (2017). The role of potassium on maize leaf carbon exportation under drought condition. Acta Physiologiae Plantarum 39(10):219. https://doi.org/10.1007/s11738-017-2515-5

Mohammed N (2018). Exploring rice genetic resources to improve nutrient use efficiency. PhD Thesis, University of York.

Moll R, Kamprath E, Jackson W (1982). Analysis and interpretation of factors which contribute to efficiency of nitrogen utilization. Agronomy Journal 74(3):562-564. https://doi.org/10.2134/agronj1982.00021962007400030037x

Neirynck J, Maddelein D, De Keersmaeker L, Lust N, Muys B (1998). Biomass and nutrient cycling of a highly productive Corsican pine stand on former heathland in northern Belgium. Annales des Sciences Forestières; 55(4):389-405. https://doi.org/10.1051/forest:19980401

Nguyen GN, Panozzo J, Spangenberg G, Kant S (2016). Phenotyping approaches to evaluate nitrogen-use efficiency related traits of diverse wheat varieties under field conditions. Crop and Pasture Science 67(11):1139-1148. https://doi.org/10.1071/CP16173

Omondi JO, Lazarovitch N, Rachmilevitch S, Kukew T, Yermiyahu U, Yasuor H (2020). Potassium and storage root development: focusing on photosynthesis, metabolites and soluble carbohydrates in cassava. Physiologia Plantarum 169(2):169-178. https://doi.org/10.1111/ppl.13060

Reis Jr RDA, Monnerat PH (2000). Nutrient concentrations in potato stem, petiole and leaflet in response to potassium fertilizer. Scientia Agricola 57(2):251-255. https://doi.org/10.1590/S0103-90162000000200009

Rengel Z, Damon PM (2008). Crops and genotypes differ in efficiency of potassium uptake and use. Physiologia Plantarum. 133(4):624-636. https://doi.org/10.1111/j.1399-3054.2008.01079.x

Rolland F, Moore B, Sheen J (2002). Sugar sensing and signaling in plants. The Plant Cell 14(1):S185-S205. https://doi.org/10.1105/tpc.010455

Saha M, Maurya BR, Bahadur I, Kumar A, Meena VS (2016). Can potassium-solubilising bacteria mitigate the potassium problems in India? Potassium solubilizing microorganisms for sustainable agriculture. Springer, pp 127-136. https://doi.org/10.1007/978-81-322-2776-2_9

Sandaña P (2016). Phosphorus uptake and utilization efficiency in response to potato genotype and phosphorus availability. European Journal of Agronomy 76:95-106. https://doi.org/10.1016/j.eja.2016.02.003

Singh SK, Reddy VR, Fleisher DH, Timlin DJ (2014). Growth, nutrient dynamics, and efficiency responses to carbon dioxide and phosphorus nutrition in soybean. Journal of Plant Interactions 9(1):838-849. https://doi.org/10.1080/17429145.2014.959570

Song W, Xue R, Song Y, Bi Y, Zhang Y (2017). Differential response of first-order lateral root elongation to low potassium involves nitric oxide in two tobacco cultivars. Journal of Plant Growth Regulation 37(10):1-14. https://doi.org/10.1007/s00344-017-9711-9

Wang JD, Hou P, Zhu GP, Dong Y, Hui Z, Ma H, ... Zhang Y (2017). Potassium partitioning and redistribution as a function of K-use efficiency under $\mathrm{K}$ deficiency in sweet potato (Ipomoea batatas L.). Field Crops Research 211:147-154. https://doi.org/10.1016/j.fcr.2017.06.021

Woodend J, Glass A (1993). Genotype-environment interaction and correlation between vegetative and grain production measures of potassium use-efficiency in wheat ( $T$. aestivum L.) grown under potassium stress. Plant and Soil 151(1):39-44. https://doi.org/10.1007/BF00010784 
Zelelew DZ, Lal S, Kidane TT, Ghebreslassie BM (2016). Effect of potassium levels on growth and productivity of potato varieties. American Journal of Plant Sciences 7(12):1629-1638. https://doi.org/10.4236/ajps.2016.712154

Zhang W, Liu X, Wang Q, Zhang H, Li M, Song B, Zhao Z (2018). Effects of potassium fertilization on potato starch physicochemical properties. International Journal of Biological Macromolecules 117:467-472. https://doi.org/10.1016/j.ijbiomac.2018.05.131

Zhou T, Du Y, Ahmed S, Liu T, Ren M, Liu W, Yang W (2016). Genotypic differences in phosphorus efficiency and the performance of physiological characteristics in response to low phosphorus stress of soybean in southwest of China. Frontiers in Plant Science 7:1776. https://doi.org/10.3389/fpls.2016.01776

Zörb C, Senbayram M, Peiter E (2014). Potassium in agriculture-status and perspectives. Journal of Plant Physiology 171(9):656-669. https://doi.org/10.1016/j.jplph.2013.08.008

Zushi K, Matsuzoe N (1998). Effect of soil water deficit on vitamin C, sugar, organic acid, amino acid and carotene contents of large-fruited tomatoes. Journal of the Japanese Society for Horticultural Science 67(6):927-933. https://doi.org/10.2503/jjshs.67.927

OPEN ACCESS

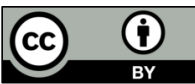

The journal offers free, immediate, and unrestricted access to peer-reviewed research and scholarly work. Users are allowed to read, download, copy, distribute, print, search, or link to the full texts of the articles, or use them for any other lawful purpose, without asking prior permission from the publisher or the author.

License - Articles published in Notulae Botanicae Horti Agrobotanici Cluj-Napoca are Open-Access, distributed under the terms and conditions of the Creative Commons Attribution (CC BY 4.0) License.

(c) Articles by the authors; UASVM, Cluj-Napoca, Romania. The journal allows the author(s) to hold the copyright/to retain publishing rights without restriction. 